PRO EXPERIMENTIS

\title{
A Method for Quantitative Assessment of Experimentally Produced Ulcers in the Stomach of Albino Rats
}

Attempts have been made in various ways to solve the problem of quantification of gastric ulcers. Different grades of ulcerations in the stomach (minimal, moderate, etc.) have been expressed ${ }^{1,2}$. MADDEN et al. ${ }^{3}$ classified ulcers on the principle of 'all or none'. Various scoring systems have been described in order to express gastric ulcers and to calculate ulcer indices ${ }^{4,5}$. Principally in all the scoring systems, the number of ulcers have been given importance for the assessment of their severity. In this study, a scale prepared on the basis of the ratio between the area of gastric mucosa and the area of ulceration has been used in order to calculate the ulcer indices.

Materials and methods. Ulcers have been produced in the stomach of albino rats having a body weight ranging between 62 and $126 \mathrm{~g}$, under 2 experimental conditions: (1) restraint technique after BRODIE and HANsON ${ }^{6}$, and (2) pylorus ligation technique after SHAY et al. ${ }^{7}$. 20 animals have been used for the first experiment and 22 for the second.

At the end of each experiment, the stomach is removed from the body, opened along the greater curvature, cleaned and spread on cardboard with the mucous surface upwards avoiding corrugation. Tracing paper is placed over the stomach and the outline of the stomach and the areas of erosions of ulceration are traced on it. This is

Table I. Scale for determining the ulcer index

\begin{tabular}{|c|c|c|c|}
\hline $\begin{array}{l}\text { Area of stomach } \\
\text { mucosa divided by } \\
\text { area of ulceration } \\
\text { in } \mathrm{mm}^{2} \text { scale }\end{array}$ & $\begin{array}{l}\text { Ulcer } \\
\text { index }\end{array}$ & $\begin{array}{l}\text { Area of stomach } \\
\text { mucosa divided by } \\
\text { area of ulceration } \\
\text { in } \mathrm{mm}^{2} \text { scale }\end{array}$ & $\begin{array}{l}\text { Ulcer } \\
\text { index }\end{array}$ \\
\hline No ulcer & 0 & $41-50$ & 0.6 \\
\hline $91-100$ & 0.1 & $31-40$ & 0.7 \\
\hline $81-90$ & 0.2 & $21-30$ & 0.8 \\
\hline $71-80$ & 0.3 & $11-20$ & 0.9 \\
\hline $61-70$ & 0.4 & $1-10$ & 1.0 \\
\hline $51-60$ & 0.5 & Each perforation & 1.0 \\
\hline
\end{tabular}

If the ratio is 101 and above, ulcer index can be calculated in the order of $0.09,0.08$, etc.

Table II. Effect of restraint and pylorus ligation on formation of ulcers in the stomach of albino rats

\begin{tabular}{llll}
$\begin{array}{l}\text { Experimental condition } \\
\text { and number of animals }\end{array}$ & $\begin{array}{l}\text { Incidence of } \\
\text { ulceration }\end{array}$ & $\begin{array}{l}\text { Ulcer index } \\
\text { range }\end{array}$ & Ulcer index \\
\hline Restraint method (20) & $90 \%$ & $0-0.4$ & $0.22 \pm 0.13$ \\
$\begin{array}{l}\text { Pylorus ligation method } \\
(22)\end{array}$ & $90.9 \%$ & $0-0.9$ & $0.54 \pm 0.21$ \\
\hline
\end{tabular}

Statistical treatment: $t$ value for ulcer index $=5.92$ highly significant. Ulcer index values are mean \pm S.D. then superimposed on graph paper having a millimetre scale. The total area of the stomach mucosa and the area of ulcerations are measured. An arbitrary scale (Table I) has been evolved in order to express the results and accordingly the ulcer index is calculated. If there is any perforation, an ulcer index of 1.00 per perforation should be added to the index obtained by the above method.

Results. The results have been summarized in Table II, which shows that out of the 2 methods in pylorus ligation technique the mean ulcer index value is $2^{1 / 2}$ times more than that produced by the restraint technique, although the incidence of ulceration is almost the same. However, perforation was not present in any.

Discussion. In this method equal status has not been given to a big or a small ulcer because it is one in number; on the other hand, they have been treated separately depending on their area of involvement, thus avoiding the possibility of getting statistically correct but biologically misleading results. Since the total area of ulceration in relation to the total area of each stomach is taken into consideration for assessment, it appears that the quantification by this procedure becomes more accurate than any other.

The increased effectiveness of the pylorus ligation technique in production of ulceration appears to be due to the exposure of gastric mucosa to the corrosive action of accumulating acid in the stomach, over and above the stress of operation ${ }^{8}$.

Résumé. Pour évaluer quantitativement les ulcères provoqués expérimentalement dans l'estomac des souris blanches, on dresse le tableau exprimant le rapport entre la muqueuse gastrique et la surface totale d'ulcération indice de l'ulcère. Il semble que la méthode décrite donne des résultats plus exacts car elle tient compte de l'étendue totale d'ulcération en fonction de la surface totale de l'estomac.

Department of Physiology,

A. K. Ganguly Jawaharlal Institute of Post-Graduate Medical Education and Research, Pondicherry-6 (India), 16 June 1969.
1 W. E. Hambourger, L. D. Calvin and D. A. Houlahan, J. Pharmac. exp. Ther. 106, 392 (1952).

2 W. ANDERSON and P. D. SOMAN, Nature 199 (1963).

3 R. J. Madden and H. H. Ramsburg, Gastroenterology 18, 128 (1951).

4 E. A. Risley, W. B. Raymond and R. H. Barnes, Am. J. Physiol. 750,754 (1947).

5 A. Robert and J. E. Nezamis, Proc. Soc. exp. Biol. Med. 98, 9 (1958).

6 D. A. Brodie and H. M. Hanson, Gastroenterology 38, 353 (1960).

7 H. Shay, S. A. Komarov, S. S. Fels, D. Meranze, M. GruenSTEIN and H. Siplet, Gastroenterology 5, 41 (1945).

8 The author gratefully acknowledges the encouragement and guidance provided by Dr. S. K. LAL, Professor of Physiology JIPMER, Pondicherry, and the skilled technical assistance given by Mr. S. K. SREEPATHI RAO in bringing out this paper. 